\title{
A TRIAL OF RAPPAPORT'S MEDIUM
}

\author{
BY \\ PATRICK COLLARD AND MARIAN UNWIN \\ From the Department of Bacteriology, University College Hospital, Ibadan
}

(RECEIVED FOR PUBLICATION APRIL 24, 1958)

In August, 1956, Rappaport, Konforti, and Navon published an account of a new enrichment medium for certain salmonellae. They claimed that their medium was superior for the culture of salmonellae from faeces to selenite $F$ medium and tetrathionate broth except in the case of Salmonella typhi.

\section{Materials and Methods}

Rappaport's medium was tried out in parallel with, and in combination with, tetrathionate broth, and selenite $\mathrm{F}$ medium in 1,000 consecutive stool cultures.

Media.-Selenite F medium, tetrathionate broth, and desoxycholate-citrate-agar (D.C.A.) were made according to the formulae by Mackie and McCartney (1953). Rappaport's medium was prepared according to the formula given by Rappaport et al. (1956).

In order to make allowance for the effect of inoculating more bottles, and to test the effect of previous dilution of faeces upon the efficacy of each of the selective media, each specimen was inoculated into all three media both with a small inoculum, that is, 5 drops of a $1: 1,000$ suspension of faeces in saline, and with a large inoculum, a particle of faeces as big as a pea.

After incubation for approximately 18 hours at $37^{\circ}$ C. a loopful from each of the six tubes was plated on to desoxycholate-citrate-agar. After a further overnight period of incubation non-lactose-fermenting colonies were picked off the D.C.A. plates, subcultured on litmus lactose agar to check purity, and when pure investigated biochemically, and, if apparently salmonellae, subjected to serological testing.

TABLE I

COM PARISON OF EFFICIENCY OF DIFFERENT ENRICHMENT MEDIA

\begin{tabular}{l|c|c|c|c|c|c|c|c|c}
\hline & \multicolumn{7}{|c}{ No. of Strains Isolated from Salmonella } \\
& A & B & C & D & E & F & Others & Total \\
\hline $\begin{array}{l}\text { Selenite F+tetra- } \\
\text { thionate broth }\end{array}$ & $\cdots$ & - & 2 & 2 & 1 & 7 & 2 & 2 & 16 \\
$\begin{array}{c}\text { Selenite F } \\
\text { Selenite F+tetra- } \\
\text { thionate broth } \\
\text { Rappaport's medium }\end{array}$ & - & - & 4 & 5 & 2 & 8 & 3 & 4 & 26 \\
\hline
\end{tabular}

\section{Results}

From the 1,000 specimens of stool 31 strains of salmonellae were isolated by one or other enrichment medium or direct plating on D.C.A. The distribution of these according to the medium or combination of media with which they were isolated, and according to groups, is shown in Table I.

\section{Discussion}

It is clear from the above results that the addition of a tube of Rappaport's medium to the usual combination of one tube each of selenite $F$ and tetrathionate broth increased the number of isolations of salmonellae from the routine stoop examined by about $60 \%$ (16 to 26 ).

It is of some interest to consider how far thi increase in the number of strains isolated is due to the specific qualities of the medium, and how far it is accounted for merely by the addition of one further tube irrespective of the medium.

As can be seen from Table I Rappaport's medium used alone (one tube) was superior to single tubes of either selenite $F$ or tetrathionate broth and approximately as efficient as a combination of one tube of each of the two conventional media.

TABLE II

EFFECT OF DIFFERENT COMBINATIONS OF TUBES OF ENRICHMENT MEDIA

\begin{tabular}{|c|c|c|c|c|}
\hline & $\underset{F}{\text { Selenite }}$ & $\begin{array}{c}\text { Tetra- } \\
\text { thionate } \\
\text { Broth }\end{array}$ & $\begin{array}{l}\text { Rappa- } \\
\text { port's } \\
\text { Medium }\end{array}$ & $\begin{array}{l}\text { No. of } \\
\text { Strains } \\
\text { Isolated }\end{array}$ \\
\hline $\begin{array}{l}\text { Single tube of enrichment } \\
\text { medium }\end{array}$ & + & + & 1 & $\begin{array}{l}11 \\
10\end{array}$ \\
\hline $\begin{array}{l}\text { Two tubes of the same enrich- } \\
\text { ment medium }\end{array}$ & + & + & + & $\begin{array}{l}14 \\
14 \\
17\end{array}$ \\
\hline $\begin{array}{l}\text { Two tubes one of each enrich- } \\
\text { ment medium }\end{array}$ & + & + & + & $\begin{array}{l}17 \\
16 \\
18 \\
16\end{array}$ \\
\hline $\begin{array}{l}\text { Three tubes one of each en- } \\
\text { richment medium }\end{array}$ & + & + & + & 26 \\
\hline $\begin{array}{l}\text { Four tubes two each of two } \\
\text { enrichment media }\end{array}$ & + & $\begin{array}{l}+ \\
+\end{array}$ & + & $\begin{array}{l}21 \\
24 \\
24\end{array}$ \\
\hline $\begin{array}{l}\text { Six tubes two of each enrich- } \\
\text { ment medium }\end{array}$ & + & + & + & 29 \\
\hline
\end{tabular}


Table II shows that, while the duplication of tubes of the same medium does increase the number of strains isolated, it was not in the case of tetrathionate and selenite as effective as adding a second tube of the other medium. Two tubes of Rappaport's medium gave almost the same increase in number of strains isolated as the tube of Rappaport's medium and one tube of either of the other two media.

Three tubes, one of each of the three different media, gave a much higher number of strains isolated than any combination of three or even four tubes which involved only two different media.

It is interesting to note that the difference made by using the heavy or the light inoculum (Table III) supported the use of the dilute inoculum for

TABLE III

EFFECT OF INOCULUM SIZE ON NUMBER OF ISOLATIONS WITH THE THREE MEDIA

\begin{tabular}{|c|c|c|c|c|}
\hline & & & $\begin{array}{l}\text { Heavy Inoculum } \\
(1: 1)\end{array}$ & $\begin{array}{l}\text { Light Inoculum } \\
(1: 1,000)\end{array}$ \\
\hline $\begin{array}{l}\text { Selenite .. } \\
\text { Tetrathionate } \\
\text { Rappaport }\end{array}$ & $\begin{array}{l}\ldots \\
\cdots\end{array}$ & $\begin{array}{l}\ldots \\
\cdots \\
\cdots\end{array}$ & $\begin{array}{l}11 \\
10 \\
12\end{array}$ & $\begin{array}{r}10 \\
8 \\
16\end{array}$ \\
\hline
\end{tabular}

(Number of strains isolated.

Rappaport's medium and the heavy inoculum for selenite $F$ and tetrathionate broth, but was very much less than might be expected with the latter two media.

\section{Conclusion}

Rappaport's medium is a useful addition to the selective media in use to-day. The addition of one tube of Rappaport's medium to the selenite and tetrathionate in routine use in this laboratory increased the number of isolations by enrichment media from 16 to 26 in 1,000 consecutive unselected stools.

In our hands the sensitivity index of the new medium was not as high as that reported by Rappaport and his colleagues. Taking the "sensitivity index" (S.I.) as the ratio between the number of strains of salmonellae isolated from the population of faecal specimens by the medium under consideration, and the total number of strains isolated from the specimens by any method, in this laboratory the sensitivity index for each medium was as follows: Tetrathionate alone $32 \%$, selenite alone $35 \%$, Rappaport's medium alone $48 \%$, selenite + tetrathionate $52 \%$, selenite + tetrathionate + Rappaport $84 \%$. In the small series reported here there did not appear to be any difference in the efficiency of Rappaport's medium in the isolation of salmonellae of group D, but it did not seem to be as effective as selenite and tetrathionate for the isolation of salmonellae of group $\mathrm{E}$.

\section{REFERENCES}

Mackie, T. J., and McCartney, J. E. (1953). Handbook of Practica Bacteriology, 9th ed. Livingstone, Edinburgh and London. Rappaport, F., Konforti, N., and Navon, B. (1956). J. clin. Path., 9,261 . 